\title{
The Paradox of Jonah: Response to "Solving the Riddle of Frightening Near-Death Experiences"
}

\author{
Nancy Evans Bush, M.A. \\ Bolton, $C T$
}

ABSTRACT: Kenneth Ring has suggested that frightening near-death experiences (NDEs) can be explained as reactions to inadequate anesthesia or as phantasmagories thrown up by a resistant ego. By contrast, I contend that these same arguments have been used by skeptics to question the validity of the radiant NDE; that as they have been found inadequate there, so they do not adequately address the meaning or value of the terrifying experience; and that experiences of the depths may be equally productive and as worthy of serious study as are experiences of radiance.

During the still-brief life of the field of near-death studies, a major educational task has been to counter the arguments of reductionism. Confronted by accounts of experiences that do not fit the prevailing model of medical thought and scientific materialism, skeptics have claimed that near-death experiences (NDEs) are merely meaningless byproducts of physiological and/or psychological processes. The argument is, "It's only ..." - the effects of anoxia, drugs, medications, temporal lobe dysfunction, depersonalization, hallucination, birth recollection, or a number of other explanations. In any of these skeptical interpretations, the precipitant, not the experience itself, becomes the focus of interest; the mechanics of the process may be of interest, but the NDE itself is rationalized as nonexistent, its meaning and value in the life of the experiencer dismissed as irrelevant.

Nancy Evans Bush, M.A., is a writer, editor, and pastoral counselor in private practice, and is President of the International Association for Near-Death Studies. Reprint requests should be addressed to Ms. Bush at P.O. Box 9486, Bolton, CT 06043. 
In "Solving the Riddle of Frightening Near-Death Experiences," Kenneth Ring (1994), unquestionably the dean of near-death studies, confronted experiences that do not fit the prevailing model of neardeath thought. It is a curious irony that his response falls squarely into the reductionist mode, albeit reductionism of a somewhat different order. As he has for so long argued that it is their presuppositions that have kept the skeptics from recognizing radiant NDEs as something more than empty physiological and psychological responses, so I suggest that a different set of presuppositions, based on the prevailing myth of the glorious NDE, can blind one to recognizing in the phenomenology of terror an invitation equally valid: the better known, and understandably more popular, NDE marks an encounter with the heights of spiritual experience; the other, with its depths.

\section{The Pharmacological Explanation Revisited}

Noting that anesthesia may sometimes produce frightening effects, and that the void experiences appear identical to one aspect of the perinatal experiential model identified by Stanislav Grof (1975) in his work with psychedelics, Ring concluded that terrifying experiences of the void "are not true NDEs as such but are essentially emergence reactions to inadequate anesthesia ... further intensified by initial resistance and fear."

The pharmacological explanation of NDEs was first discussed in 1975, with the publication of Raymond Moody's Life After Life. Its inconclusiveness was noted by Ring himself in his first book in this field, Life at Death (1980), and later by Michael Sabom (1982); this and other reductionistic theories have been thoroughly examined by Carol Zaleski (1987), who also observed weakness in the argument. If the pharmacological theory is inadequate as explanation of radiant NDEs, it is difficult to understand how it should now be considered sufficient as explanation of one type of frightening experience.

Further, considering Ring's study of mysticism and the Mystery Schools $(1985,1988)$, "Solving the Riddle of Frightening Near-Death Experiences" displayed a curious innocence of the existence of the void as a significant element in deep spiritual experiences across many traditions. One also wonders at his failure to mention that Grof's perinatal matrix contains all NDE experience categories-radiant and hellish as well as the void. The model includes experiences of cosmic engulfment, "no exit," death and rebirth, cosmic unity and transcendence, and transpersonal characteristics; the imagery sweeps through 
tunnels, eschatological visions of dreadful monsters and titanic struggles, the slaying of demons, emergence into radiance, visions of paradise, and revelations of universal knowledge; there may be out-of-body experiences, encounters with spirits of the deceased, life review, and ineffable bliss (Grof, 1980). In fact, Grof has noted that among transpersonal experiences, "The ultimate experience appears to be that of the mysterious primordial emptiness and nothingness that contains all of existence in a germinal form, the void" $(1980$, p. 31)-and encountered by an unready self, this would likely be experienced as terrifying. Surely there is more to be said about these experiences of the void than they are "not true NDEs as such" but merely an anesthesia emergence reaction.

\section{Metaphor and Ilusion}

Ring has provided the helpful tag of "inverted" for the first type of terrifying NDE observed by Bruce Greyson and me (1992) in our sample of 50 cases, in which "hellish" and "void" appear as the other two types. The inverted and hellish experiences remain marginally within Ring's definition of possible near-death experience, but only because they may transform to the classic radiant pattern.

Given a selected premise from Eastern tradition (that ego and the physical world are illusion), Ring argued that terrifying NDEs "merely reflect the fact that hell is actually the experience of an illusory separative ego fighting a phantom battle." Using as secondary premise the underlying assumption of $A$ Course in Miracles (1975) ("what's real-and the only thing that's real-is what NDErs call 'the Light' "), he came to the only possible logical conclusion, that "frightening NDEs therefore ... aren't real." So, in their terrifying aspects, these experiences were dismissed as "illusory phantasmagories." Only the radiant NDE could be considered "a leaking through of ultimate reality."

It hardly bears saying that to an individual struggling with the profound aftereffects of a frightening NDE, as to his or her therapist or pastor, it may be of limited value to learn of the life-shaping event that nothing happened.

One problem here is that of mixed levels of discourse: a tumbling of metaphysics and testable hypotheses, spiritual and psychological language, "that world" and "this world" realities. At the level of theory and spiritual metaphor, Ring's discussion of course rings true. Yet ego is illusory in the same manner in which a tree is illusory: however well one knows that at the subatomic level a tree is mostly space with 
widely scattered, busy blips of activity, only Buckaroo Banzai (Rauch, 1984) can manage the feat of maneuvering through subatomic space. At the level of daily life, that same tree, too rapidly encountered, will maim or kill.

At this level, ego provides the organizing center around which we build our conscious lives and from which we are enabled to develop a functioning self. Without ego, any of us will demonstrate all the psychodynamic stability of Jell-o. Without ego, as Greyson commented recently, "there's schizophrenia" (B. Greyson, personal communication, May 1993). The life of ordinary consciousness is lived at a level from which neither tree nor ego can be safely dealt with as merely, and exclusively, illusion. From the practical standpoint, Ring's dismissal of the frightening NDE as phantasmagory echoed remarkably like Ronald Siegel's (1980) insistence that all NDEs are merely hallucinations, not to be taken seriously.

Further, the degree of ego-centrality in a given individual at any given time may be determined as much by developmental process as by "personal rigidity [or] massive religious indoctrination concerning the existence of a literal hell." The ego-centrism of a younger person may be quite appropriate in terms of psychological stage of development and life tasks. To equate being unprepared to surrender the sense of hard-won self, as Ring quoted Bruce Joel Rubin (1990, p. 191), with having "spent a lifetime angrily fighting with the world" is in this sense unjust, as is the corollary, "Death is an experience of ego loss. . . . If, however, you have loved life, if you have learned to remain open to it, then death is a liberation" (Rubin, 1990, pp. 190-191). Subtle but implicit in Rubin's words is a modern-day version of the ancient idea that "good" people (not sinners now, but those able to "let go of ego") will be rewarded and "bad" people (those perceived as overcontrolling or rigid) will be punished. It is a secular variant of the concepts of literal heaven, hell, and judgment for sin, no less spiritually injurious to all parties for having cast out theological language.

Without the tinge of judgmentalism inherent in that approach, Grof himself has noted:

[These] mythologies and concepts of God, heaven and hell do not refer to physical entities, events in time or geographical locations, but to psychic realities experienced during altered states of consciousness. These realities [note plural-N.E.B.] are an intrinsic part of the human personality that cannot be repressed and denied without serious damage to the quality of human life. For the full expression of human nature, they must be recognized, acknowledged and explored, and in 
this exploration, the traditional depictions of the afterlife can be our guides. $(1980$, p. 31)

The "full expression of human nature," then, cannot be limited to the likable and wanted. "Life," wrote W. Brugh Joy, "seeks to be fully expressed" (1990, p. 232). He also wrote, "Life Itself teaches dramatically and powerfully through events centered around crisis, loss, and death. When such events are not embraced-when the dark, the demonic, and the destructive are not integrated-the conscious mind partitions itself from total consciousness and creates a reality reflecting only that which is acceptable to one's conscious awareness" (1990, p. 331). If the riddle of frightening experiences is to be found authentically, it must be in the fullness of nature, human and otherwise, and in the totality of consciousness and of the universe itself.

\section{The Riddle of Frightening Experiences}

No one-absolutely no one-wants to know about the experiences of cosmic terror. It is no surprise that frightening near-death experiences have remained for so long unspoken, or that even the best of minds will attempt to argue them away. The horrific experience brings us face to face with the deepest of all human wounds, what Sören Kierkegaard termed "dread," the knowledge of our mortality, and the radical knowledge that being contains both nova and black hole, light and darkness, radiant bliss and intolerable horror, Christ and Lucifer. The titanic power of the core spiritual experience, whether radiant or terrifying, is that is plunges so radically and deeply into the nature of being, respecting neither readiness nor desire.

Of writers about near-death experiences, it was Zaleski (1987) who first and most cogently examined the contemporary tendency to admit only the congenial, the "garden of unearthly delights," for exploration. Yet nothing in centuries of human spiritual experience supports the conclusion that enlightenment, salvation, or self-actualization are onedimensional exercises in a reality involving only rapturous encounters with a beneficent oneness. Beyond the wistful assumptions of much contemporary talk about spirituality lies a difficult truth: that dualism cannot be reconciled by attending to only one of its aspects. Paradox is an uncomfortable life partner.

The same St. Paul who wrote, "I am convinced that there is nothing ... that can separate us from the love of God" (Romans 8:39) could also write, "It is a fearful thing to fall into the hands of the living God!" 
(Hebrews 10:31). Like Arjuna in the Bhagavad Gita, we prefer to see the "good" side of Krishna, God-the beautiful, the Being of Light, the unconditionally loving, bliss-bringing, the Creator and giver of life and joy. Like Arjuna, we recoil in terror from the dark, horrific aspects of self/Self, Godhood, and the universe. It is easier to plead to the sentimental Jesus of our longing than to the battered and despairing Jesus hanging bloodily on crossed posts. We would embrace II Isaiah more than Jeremiah, the sweet-faced Virgin Mary rather than the monstrous, bloody, and death-dealing Kali. Yet, to use Christian metaphor, Good Friday precedes Easter, and both are contained within the Resurrection. As Joseph Campbell has written, the god unrecognized appears as a demon (Campbell and Moyers, 1988). We will strive for the death of our ego rather than face our demons and our darkness.

The riddle of frightening near-death experiences cannot be solved either by evasion or by dismissal; it cannot be "solved" at all, but only glimpsed and lived. May Sarton has written (1974):

Kali, be with us.

Violence, destruction, receive our homage.

Help us to bring darkness into the light ...

Crude power that forges a balance

Between hate and love.

The key seems to lie with reconciliation, with that incongruous balance of Sarton's poem. This is so difficult to fathom! Naomi Ruth Lowinsky, writing of the Kali aspect of the feminine (a quality in men as well as women), observed that "the red, fiery, passionate, bloody aspects of our nature, and the black, death-dealing, underworld aspects of women have been demonized" (1992, p. 188). Yet universally, what remains hidden and repressed becomes the beast that will devour us, individually and collectively; kept down, shadow, like pressurized magma in Mt. St. Helen's, has a nasty way of squirting sideways, destroying everything in its path.

Jonah, too, tried to "escape from the Lord." No doubt he, too, floundered in terror to avoid sinking into the depths, into the maw of the great fish. "The whale," wrote Campbell, "represents the power of life locked in the unconscious" (Campbell and Moyers, 1988, p. 146). Of stories in which the protagonist, the experiencer, is sucked into the abyss, he commented:

The conscious personality here has come in touch with a charge of unconscious energy which it is unable to handle and must now suffer all the trials and revelations of a terrifying night-sea journey, while 
learning how to come to terms with this power of the dark and emerge, at last, to a new way of life. (p. 146)

The task is not to deny the experience its share of reality, but "to come to terms with this power of the dark." The result, no less than with radiant encounters, can be transformation.

Michael Grosso, referring to radiant experiences, has observed that "For many, the NDE serves as a tool of deconstruction," leading to "a liberating disillusionment" $(1991$, p. 57$)$. This is no doubt the point Ring was after, but Grosso's argument is less narrow and therefore more persuasive, and applies as well to frightening experiences:

I am trying to make explicit the mythic intentionality that seems at work in the NDE. I am not trying to explain it in the sense of reduce it to an a priori set of ideas or ontological presuppositions. I am rather, in a spirit of active imagination, trying to carry the myth forward, see where it wants to go, immerse myself in its élan vital, its meandering evolutionary impetus.

So let us enter into the flow of the near-death imagery. Instead of trying to figure out whether it is an illusion or a defense mechanism or a phantasm conjured by some brain mechanism, let us enter into the mythic near-death journey and see where it leads us. (pp. 57-58)

I couldn't have said it better. One need not-and had perhaps better not-dismiss the experience of the abyss or the void or the seemingly demonic as illusion with no ontological substance. And at the level at which the horrific experience is brought into daily living-that is, at the this-world, incarnational, stage-developmental level of physical and psychological being-exploration of symbol, metaphor, and meaning will certainly be more productive as a starting point than dismissal on abstract theoretical grounds.

It is past time to accord to frightening NDEs the same level of consideration that has been granted to radiant experiences. In this regard, Ring's hypotheses are welcome. They can, should, and no doubt will be tested; one hopes the testers will approach their task recognizing that what the hypotheses will yield is demographic and descriptive data about precipitating factors, not information about the experience or its incorporation into the fullness of human life and meaning.

No one knows the number of individuals whose lives are being shaped in the awesome, awakened consciousness of a "realer than real," terrifying encounter. They-and all of us-deserve to hear more than "It's only ...." 


\section{References}

Campbell, J., and Moyers, B. (1988). The power of myth. New York, NY: Doubleday.

Greyson, B., and Bush, N.E. (1992). Distressing near-death experiences. Psychiatry, 55, 95-110.

Grof, S. (1975). Realms of the human unconscious. New York, NY: Viking.

Grof, S. (1980). Beyond death. New York, NY: Thames and Hudson.

Grosso, M. (1991). The myth of the near-death journey. Journal of Near-Death Studies, $10,49-60$.

Joy, W.B. (1990). Avalanche: Heretical reflections on the dark and the light. New York, NY: Ballantine.

Lowinsky, N.R. (1992). The motherline: Every woman's journey to find her female roots. Los Angeles, CA: Tarcher.

Moody, R.A., Jr. (1975). Life after life. Covington, GA: Mockingbird Books.

Rauch, E.M. (1984). The adventures of Buckaroo Banzai. New York, NY: Pocket Books.

Ring, K. (1980). Life at death: A scientific investigation of the near-death experience. New York, NY: Coward, McCann and Geoghegan.

Ring, K. (1985). From alpha to omega: Ancient Mysteries and the near-death experience. Anabiosis: The Journal of Near-Death Studies, 5(2), 3-16.

Ring, K. (1988). Paradise is paradise: Reflections on psychedelic drugs, mystical experience, and the near-death experience. Journal of Near-Death Studies, 6, 138-148.

Ring, K. (1994). Solving the riddle of frightening near-death experiences: Some testable hypotheses and a perspective based on $A$ course in miracles. Journal of Near-Death Studies, this issue.

Rubin, B.J. (1990). Jacob's ladder. New York, NY: Applause.

Sabom, M.B. (1982). Recollections of death: A medical investigation New York, NY: Harper and Row.

Sarton, M. (1974). Collected poems. New York, NY: Norton.

Siegel, R.K. (1980). The psychology of life after death. American Psychologist, 35, $911-$ 931.

Zaleski, C.G. (1987). Otherworld journeys: Accounts of near-death experience in medieval and modern times. New York, NY: Oxford University Press. 